UDC 911.5:502.13:502.51(285):556.55

Ivan Platonovich Kovalchuk,

Doctor of Science (Geography), Professor, Head of the Department of Geodesy and Cartography,

National University of Life and Environmental Sciences of Ukraine,

17 Vasylkivska St., Building 6, Kyiv, 03040, Ukraine,

e-mail: kovalchukip@ukr.net, https://orcid.org/0000-0002-2164-1259;

Vitalii Oleksiyovich Martyniuk,

$\mathrm{PhD}$ (Geography), Associate professor, Professor at the Department of Ecology, Geography and Tourism,

Rivne State University of Humanities, 12 St. Bandery St., Rivne, 33028, Ukraine, e-mail: martynyukVO@gmail.com, http://orcid.org/0000-0002-8654-3510;

Vaida Šeiriené,

Doctor (Natural sciences), Senior researcher, Head of the Laboratory of Quaternary Research,

Nature Research Centre Institute of Geology and Geography, 2 Akademijos St., LT-08412, Vilnius, Lithuania, e-mail: vaida.seiriene@gamtc.lt, https://orcid.org/0000-0002-9477-2321

\title{
THE BASIN-LANDSCAPE APPROACH TO THE PROTECTION AND CONDITION OPTIMIZATION OF THE LAKES OF THE NATIONAL PARKS
}

І. П. Ковальчук, В. О. МартинюК, В. Шейрене. БАСЕЙНОВО-ЛАНДШАФТНИЙ ПІДХІД ДО ОХОРОНИ ТА ОПТИМІЗАЦІЇ СТАНУ ОЗЕР НАЦІОНАЛЬНИХ ПАРКІВ. Обтрунтовується сутність басейново-ландшафтного підходу до охорони озер національних парків як актуального напряму досліджень, шчо формується на стику природоохоронного ландшафтознавства, гідрології та геоекологї. Розкрито алгоритм дослідження, особливості аналізу та оцінки стану озернобасейнової системи (ОБС), виявлено чинники, які погіриують геоекологічний стан в озерній і басейновій субсистемах, обтрунтовано оптимізаційні заходи в об'єктах природно-заповідного фонду, що розтамовані у межах природного резервату.

Матеріалами дослідження слугували багаторічні польові ландшафтно-лімнологічні та геоекологічні дослідження авторів у межах Поліського регіону України та, зокрема, ОБС Нобельського національного природного парку. Методика дослідження трунтувалася на комплексних фізико-географічних методах, гідрологічного профілювання та створення батиметричних моделей водойм, гідрохімічної діагностики водних мас озер, геохімічних аналізів донних відкладів, ландшафтного картографування із застосуванням ГІС-технологій. На прикладі басейну озера Засвітське (Нобельський національний парк, Поліський регіон Украӥни) викладено результати його геоекологічних (ландшафтно-екологічних) досліджень, зокрема, представлені оригінальні профілі і батиметрична модель водойми, ландшафтні карти аквального комплексу і водозбору озера, лімно- і ландшафтометричні характеристики ОБС. 3 урахуванням рівня антропогенних трансформацій ОБС $і$ наявності високої частки еколого-стабілізуючих угідь (лісів, водойми природного походження), рівень стійкості ОБС оцінюється як високий. Очінка гідрологічних показників водойми та гідрохімічних характеристик дозволяє віднести дане озеро до оліготрофного типу. Результати комплексного аналізу геоекологічних параметрів стану озера Засвітське і його ландмафтнолімнологічного функиіонування свідчать про дочільність рекреаційної спеціалізачії природокористування в Нобельському начіональному парку, до складу якого входить ие озеро. Обтрунтовано пропозииї щодо кадастрової оиінки ОБС транскордонних природоохоронних територій Рамсарського типу, схарактеризовані підходи до ландиафтно-географічного зонування ОБС і до охорони аквальних об'єктів.

Ключові слова: ландшафт, басейново-ландшафтний підхід, озерно-басейнова система, природний аквальний комплекс, природний територіальний комплекс, національний парк.

И. П. Ковальчук, В. А. Мартынюк, В. Шейрене. БАССЕЙНОВО-ЛАНДШАФТНЫЙ ПОДХОД К ОХРАНЕ И ОПТИМИЗАЦИИ СОСТОЯНИЯ ОЗЕР НАЦИОНАЛЬНЫХ ПАРКОВ. Обосновывается сущность бассейново-ландшафтного подхода к охране озер начиональных парков как актуального направления исследований, формирующегося на стыке природоохранного ландшафтоведения, гидрологии и геоэкологии. Раскрыты алгоритм исследования, особенности анализа и оценки состояния озерно-бассейновой системы (ОБС), выявления факторов, ухудшаюших геоэкологическую обстановку в ее озерной и бассейновой субсистемах, обоснования оптимизачионных мероприятий в объектах природно-заповедного фонда, расположенных в пределах природного резервата.

Материалами исследования послужсили многолетние полевые ландиафтно-лимнологические и геоэкологические исследования авторов в пределах Полесского региона Украинь и, в частности, ОБС Нобельского национального природного парка. Методика исследования основывалась на комплексных физико-географических методах, гидрологического профилирования и создание батиметрических моделей водоемов, гидрохимической диагностики водных масс озер, геохимических анализов донных отложений, ландиафтного картографирования с применением ГИС-технологий. На примере бассейна озера Засвитское (Нобельский национальный парк, Полесский регион Украины) изложены результаты его геоэкологических (ландиафтно-экологических) исследований. В частности, представлены оригинальные профили и батиметрическая карта водоема, ландшафтные карты аквального комплекса и водосбора озера, лимно- и ландшафтометрические характеристики озерно-бассейновой системы. С учетом уровня антропогенных трансформаций ОБС и наличия высокой доли экологостабилизируюших угодий (лесов, водоёма природного происхождения), уровень устойчивости ОБС оценивается как высокий. Оченка гидрологических показателей водоема и гидрохимических характеристик позволяет отнести это озеро к олиготрофному типу. Результаты комплексного анализа геоэкологических параметров состояния озера Засвитское и его ландшафтно-лимнологического функиионирования свидетельствуют о иелесообразности рекреационной специализации природопользования в Нобельском национальном парке, в состав которого входит это озеро. Обоснованы предложения по кадастровой оценке озерно-бассейновых систем трансграничных природоохранных территорий Рамсарского типа, охарактеризованы подходы кландшафтно-географическому зонированию ОБС и к охране аквальных объектов.

Ключевые слова: ландшафт, бассейново-ландшафтный подход, озерно-бассейновая система, природный аквальный комплекс, природный территориальный комплекс, национальный парк.

(C) Kovalchuk I. P., Martyniuk V. O., Šeirienè V., 2020

https://doi.org/10.26565/2410-7360-2020-53-18 
Formulation of the problem. One of the viable mechanisms for preserving landscape diversity is creation of the national natural parks (NNP) or the other specially protected natural areas. The higher the "conservation index" of the areas is (namely the ratio between the actual area of the sites of the nature reserve fund (NRF) and the total area of some region), the more resistant the natural landscapes are to anthropogenic impact and the more optimal the geoecological situation is therein.

The physical-geographical region of Volyn Polissia (Ukraine), which is the region of our research, is characterized by a large number of nature reserve areas of different ranks (453 sites of NRF). In the structure of the NRF of this natural region, the national parks hold a dominant position $(39.27 \%)$, the state reserves $(36.06 \%)$ are in second place, and the nature reserves are in third place (16.12\%). About $7.0 \%$ of NRF area account for regional landscape parks. Other NRF categories (reserved tracttracts, natural monuments and the similar.) are of secondary importance. Total conservation index in the territory of Volyn Polissia, which includes the area of all NRF site categories, equals to $9.74 \%$ [38]. According to scientists of the NAS of Ukraine [36], the conservation index for Polissia Territory (province) of Ukraine should have reached $20.0 \%$ by 2020 . Today, this index in the Polissia region equals only $8.39 \%$. At the same time, the lakes represent the great potential for expanding specially protected areas, including NNP.

The trans-border Upper-Prypiat physiographic region (PGR) is the most attractive from the landscape-attraction point of view and noted by the plenty of NRF sites. NNP Prypiat-Stokhid and the newly formed Nobel National Park are located here. Some territories in this PGR are included into the global ecological network of wetlands (Ramsar), in particular, Prypiat River Floodplain, Stokhid River Floodplain, as well as the trans-border UkrainianBelarusian wetland Prypiat-Stokhid-Prostyr.

A distinguishing feature of the landscape structure of the Upper Prypiat PGR is a high proportion of land covered by lakes (1.25\%). In the total structure of surface waters, the lakes in the natural region account for $48.25 \%$ [26]. The lakes have significant biostation (habitation of waterfowl) and ecologicalhydrological importance (ensuring functioning of river, lake and bog landscapes); they are attractive in esthetical and recreational terms. The lakes form the parts of almost all NRF sites mentioned above. In landscape planning or zoning of a national natural park, the lakes in some cases serve as peculiar ecological cores of exclusive conservation value, as well as recreational, tourist or economic sites. Yearslong landscape-limnologic research that we have been performing in Ukraine provides the grounds for suggesting a basin-landscape approach (B-LA) to studying lake-basin systems (LBS) as the most current and efficient one from the point of view of lake research and evaluation of geoecological conditions thereof, justification of measures for their utilization optimization, solution of the issues of biodiversity protection and operation management. After adoption of the EU Water Framework Directive [6] in 2000 , the basin approach began to be actively used by EU countries in the integrated management of river systems and their basins. Unfortunately, the mechanisms for protection and management of aquatic ecosystems used for river basins are not always efficient for LBS.

The target of our research is to define parameters of the lake-basin landscapes structure (on the example of the lake Zasvitske, located in Nobel National Park, Ukraine), as well as limnic and landscape-metric indices of LBS geoecological condition, and the factors having impact thereon, as an important informational and analytical base for ensuring protection and operation management of LBS located in a specially protected natural area.

The lake Zasvitske is located in the eastern part of Upper-Prypiat physiographic region (fig. 1). The geographical coordinates of the central part of the lake are as follows: $N$ 51 $1^{\circ} 52^{\prime} 30.5^{\prime \prime}$ and $E$ $25^{\circ} 44^{\prime} 04.2^{\prime \prime}$. Since 1995 the basin system of the lake Zasvitske is forming a part of the ecological network structure of the Regional Landscape Park (RLP) Prypiat-Stokhid.

In accordance with the Order of the President dated 11.04.2019 (No 131/2019) "On Creation of Nobel National Natural Park" with the total area of $25318.81 \mathrm{ha}$, LBS of the lake Zasvitske was included into the newly established environmental structure. The overall view of the lake is shown in fig. 2.

Materials and methods. The research is based on field semi-mobile landscape limnologic and geoecological researches which have been conducted by the authors in the different landscapes of the physical-geographical region of Volyn Polissia, in particular, in the Regional Landscape Park PrypiatStokhid and in Nobel National Park [13; 16; 24; 26; 28]. Laboratory-analytical diagnostics of the taken samples and field data was performed in Rivne Branch of the State Institution "Soil Protection Institute of Ukraine" (soil samples, bottom deposits of the lake) and in the State Ecological Inspection of Ukraine in Rivne region (lake water). Fund materials of Kyiv Geological Survey Expedition (Kyiv GSE) were partially used in the work. Mapping models of LBS were made using the software MapInfo Professional v8.5.

The methodological base of the study is a basin concept of nature management $[12 ; 14 ; 19]$, cartographical modelling of national parks [33] and basin 


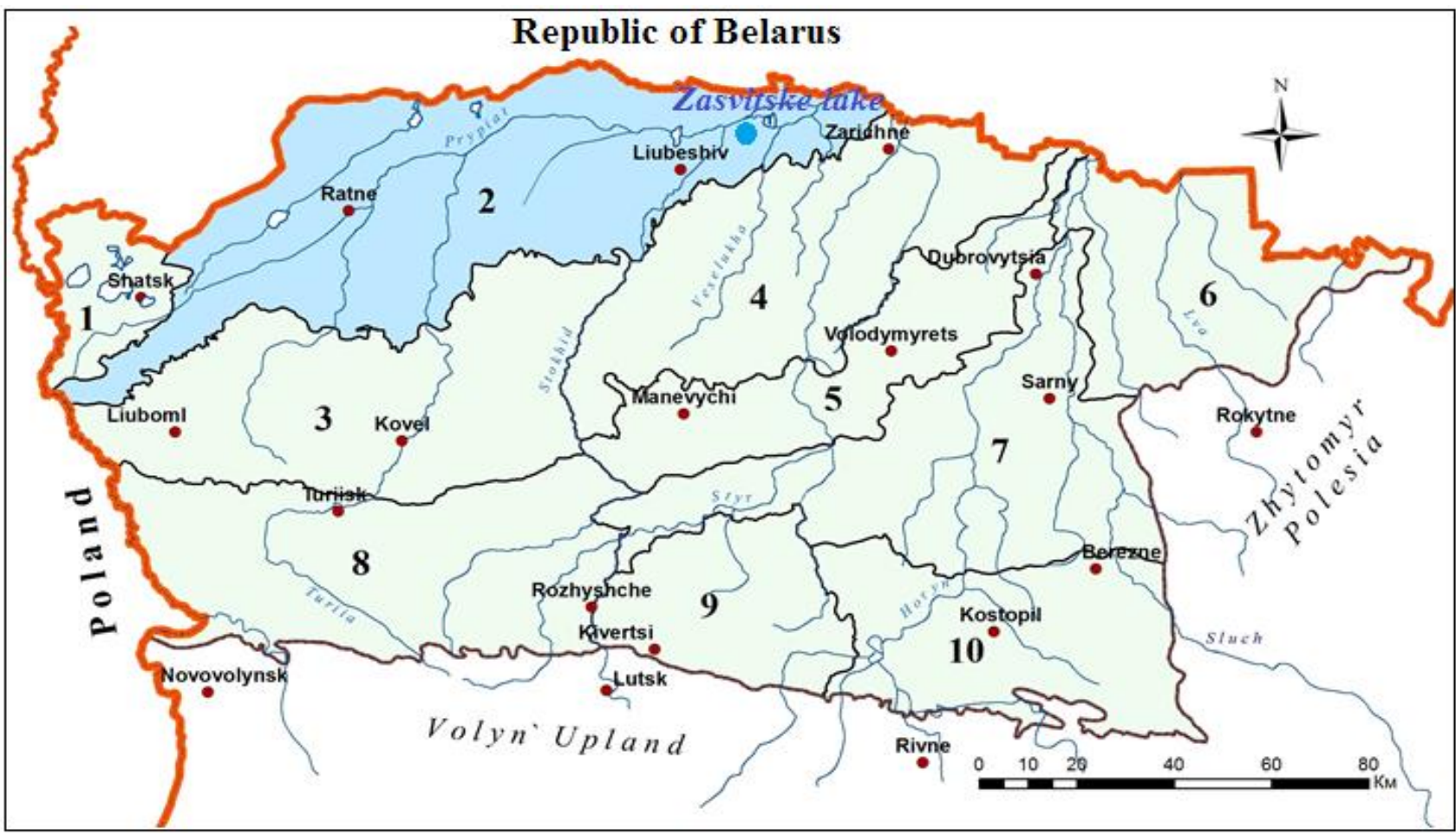

Fig. 1. Location of the basin system of Lake Zasvitske on the schematic map of physical-geographical regionalization of Volyn Polissia [25].

Legend:

Physiographic regions: 1 - Shatsk, 2 - Upper-Prypiat, 3 - Liuboml-Kovel, 4 - Lower-Styr, 5 - Manevychi-Volodymyrets, 6 - Lva-Horyn, 7 - Kolky-Sarny, 8 - Turiisk-Rozhyshche, 9 - Kivertsi-Tsuman, 10 - Kostopil-Berezne.

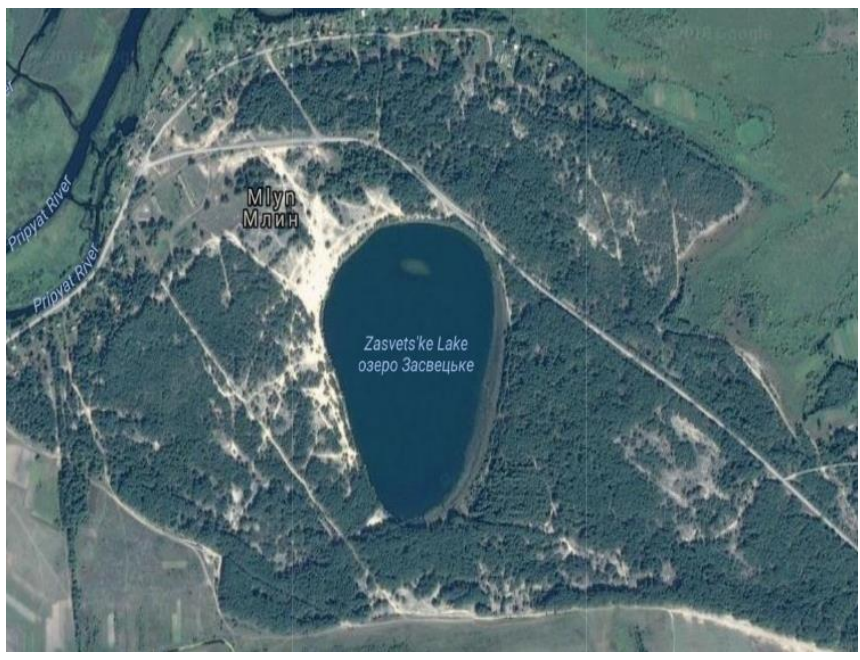

Based on the materials: Map data 2018 Google 2018 CNES / Airbus, DigitalGlobe

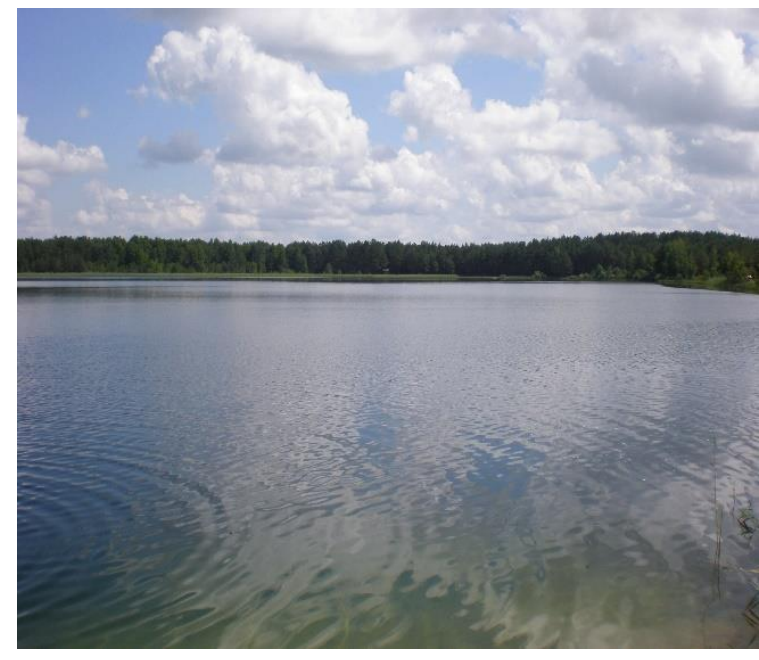

Photo by V. Martyniuk (07.08.2018)

Fig. 2. A space image of the catchment of the lake Zasvitske (on the left) and the photo of its water area (on the right)

geosystems [37], perceptions of lake-basin systems [15; 18], works on landscape monitoring [29], limnology $[3 ; 7 ; 9-10 ; 22]$, as well as the experience in landscape-limnologic analysis $[17 ; 23]$, and constructive-geographical and cartographical modelling of LBS $[15 ; 24 ; 27]$ and basin-river systems in Ukraine, as well as those located in the trans-border territories $[11 ; 40]$.

In the first decade of February 2012 we had been performing (from ice) a hydrological profiling of the park lakes, including the lake Zasvitske. Eight cross-sections were made with intervals of sounding sites at every $5.0 \mathrm{~m}$ at the lake investigated. There were in total 319 wells bored by the fishing ice bore. 
At the moment of the research, ice thickness was $0.24-0.25 \mathrm{~m}$. Uncertainty in measurement of the water body depth equalled to $0.05-0.1 \mathrm{~m}$ in separate sounding sites Using the results of the hydrological profiling of the lake, we compiled the bathymetric map of the water body (fig. 3).

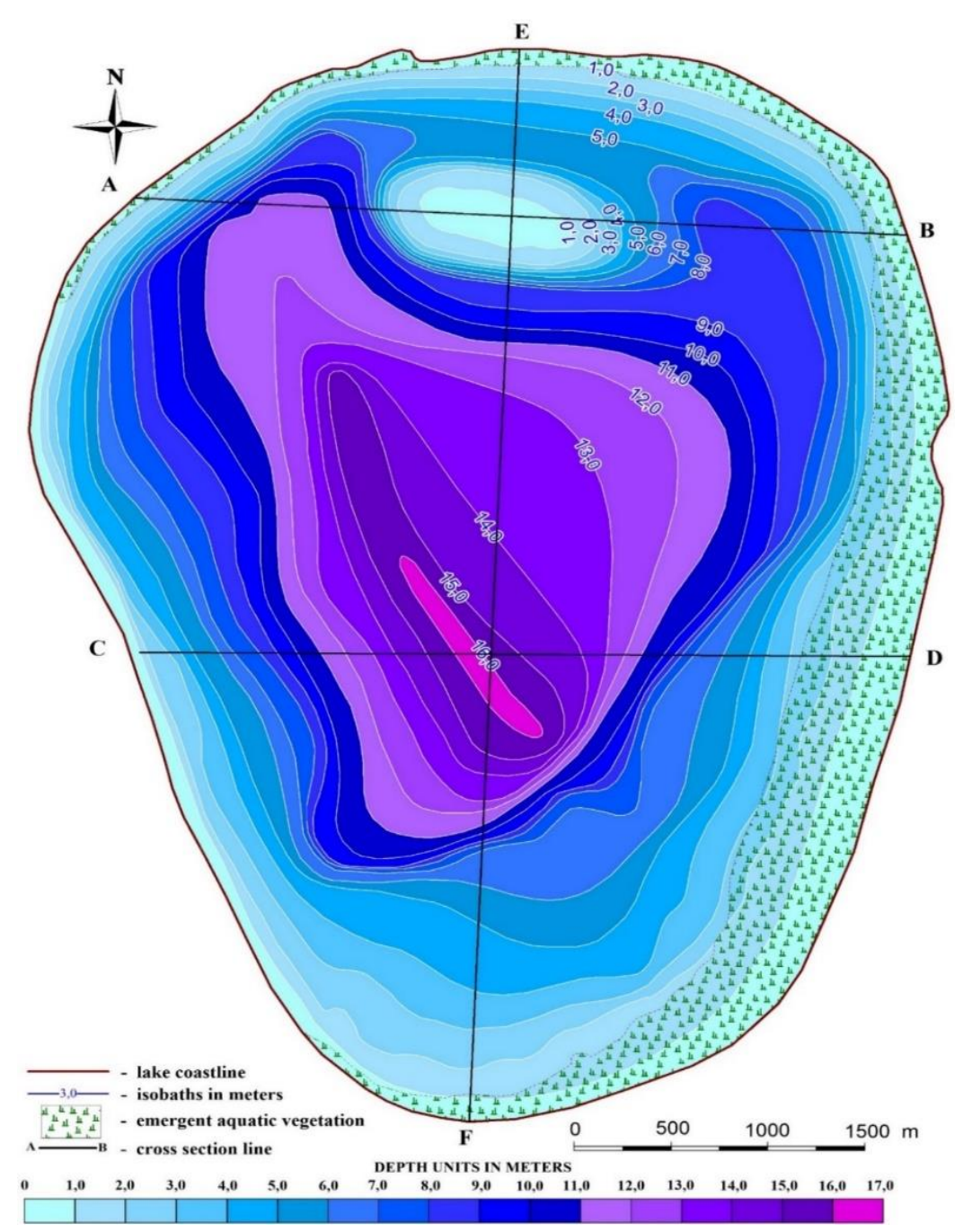

Fig. 3. Bathymetric model of the lake Zasvitske (main bathymetric profiling gates: A-B, C-D, E-F)

Hydrometric profiling and the digital bathymetric model of the lake that we made served as a basis for the landscape map creation. While composing the map, we took into consideration the peculiarities of the micro relief of the lake kettle depression, lithological composition of bottom sediments, peculiarities of geochemical processes and plant communities of the lake, as well as the features of seasonal thermic regime of the water body.

The nature of basin-landscape approach to studying LBS

The nature of B-LA lies in the fact that we consider a lake and its catchment as an integral natural (natural and economic) lake-basin system. The lake is represented as a subsystem of the lower order (as a natural-aquatic complex (NAC), and the natural territorial complexes (NTC) of various ranks of this lake catchment [18] serve as subsystems of the higher order. In terms of this methodological approach, the integral lake-basin system (LBS) serves as an operational unit of the regional ecological network, a site of predominantly recreationaleconomic use and forestry-based use, sometimes as a site of natural resource management, and as a target of management impact, namely conservational, restricting, regenerating impact and nature resource management impact.

Broadly defined, the basin approach has been known and applied in the practice of natural resource management since the first half of XX century. It is represented by the works by V. Hlushkov, R. Horton, A. Strahler, N. Makkaveev and the other scientists. The landscape hydrological approach, as a separate aspect of the basin approach, was applied in the second half of $\mathrm{XX}$ century to specific river basins by many scientists (A. Antipov, E. Zmieva, S. Zotov I. Kovalchuk, L. Korytnyi, Ya. Markus, F. Milkov, A. Obodovskyi, N. Solntsev, A. Subotin, H. Shvebs and others). 
In limnology, the lake studies from the landscape-basin perspective were beingactivated in the latter part of 1960s of XX century by the scientists of the Institute of Limnology of RAS (I. Velikoretskaia, V. Drabkova, R. Kupetskaia, N. Miroshnichenko and others) under the supervision of the academician S. Kalesnik. The works were mainly limited to compilation of landscape maps of the lake catchments and evaluation of dimensionaltypological structure of water body basins. In 1980s of the last century the limnologist O. Yakushko for the first time approached the study of the lake landscape structure as a natural aquatic complex (NAC). From the constructive-geographical positions, the lakes of Polissia region of Ukraine were studied by L. Iliin [9-10]. Similar studies are being carried out in Kazakhstan [31], Poland [39] and the USA [35], with much attention being paid to the issues of pollution of lakes with biogenic substances entering the water bodies from the surface runoff from agricultural land, evaluation of the condition of lakes in nature reserve areas, creation of inventory of lakes and the similar.

At present, B-LA has been widely applied in limnology in terms of methodology; however, there are very few publications with presented landscape maps of catchment together with NAC of lakes [2]. At the same time, an understanding of the essence of the landscape structure of a lake and its catchment does not always find an unambiguous perception among researchers, due to the fact that their search is based on different scientific concepts and algorithms. This situation is not conducive to solving the problems of protection and rational use of unique lakes located within the limits of the national parks or in the other NRF sites.

\section{systems}

Algorithm for investigation of lake-basin

The algorithm we offered for investigation of the lakes in national parks, which is based on B-LA, includes three stages: 1) preparatory stage (selection and analysis of different-time cartographic sources, space and aerial photographs; selection of representative catchments, in other words, those typical for a certain type of landscapes, preparation of a topographic basis for compilation of landscape maps; preliminary decoding of space and aerial photographs, compilation of maps of landscape outlines of lake basins); 2) field stage (instrumental measurements, referencing to real coordinates using a GPS navigator, measurements of depths, water temperatures, hydrological profiling and compilation of bathymetric maps of lake kettle depression; sampling water, bottom sediments and soils within the limits of the catchment; analysing the species diversity of hygrophytes; compilation of preliminary maps of NAC and its morphological units); 3) cam- eral stage (laboratory analysis of water, samples of bottom sediments and soils of water catchments, and vegetation; correction of field landscape maps, creation of basic landscape maps of NAC of lakes and NTC of their water catchments).

Our experience in LBS investigation $[17 ; 23$; 24] shows that the use of the results obtained on the basis of B-LA for the national natural parks with a high ratio of lake surface to drainage area of the territory will provide the possibility to enhance efficiency of reserved-recreational nature management, improve their geoecological condition, preserve valuable nature reserve sites, solve the problems of geoecological monitoring, protection and operation management thereof. The nature of B-LA in relation to protection of the lakes of the national parks is represented by the block scheme showing the main directions of LBS condition evaluation, sequence of research steps and targeting of optimizing measures (table 1).

\section{RESULTS AND DISCUSSION}

The lake Zasvitske is a water body of rounded form with a small extension in the northern part. The slopes of the lake kettle depression are steep. The bottom is sandy; in the north-eastern part in the littoral area it is sandy-muddy. The shores are raised and dry. Aquatic vegetation is developed as a narrow strip (up to 15-25 m) along the eastern and southern shores and is mainly represented by cattail and bulrush. Submerged vegetation is represented by water weed and is mainly developed along the shores. The processes of overgrowing of the lake shallow water cover about $10 \%$. The foreshore is covered by meadow forbs and tree vegetation (pine, alder, birch). There is a beach located in the western part of the lake terrace in open sandy areas.

Water surface area of the lake Zasvitske is 0.22 $\mathrm{km}^{2}$. The lake length is $0.62 \mathrm{~km}$; average width is about $0.35 \mathrm{~km}$. We found the maximum depth of the water body which is $16 \mathrm{~m}$. Average depth is $12.7 \mathrm{~m}$. The length of the lake shoreline is $1.74 \mathrm{~km}$. The lake water capacity is 5045.6 thousand $\mathrm{m}^{3}$. We have performed calculations of some limnologic coefficients, as well as those of indices in the "lake-catchment" system (table 2). They show both the current LBS condition and the potential for changes and development thereof.

LBS limnometric characteristics provided are, in fact, reference ones, they will be included into the hydrological block of the water body ecological passport and are important for comparison with the other lakes of the national park. Atmospheric precipitation and ground water of marly-chalky horizon are the main feed source of the lake. The latter aspect has been proved by divers who, when dived at the depth of 14.5-15.5 m, saw a peculiar diffusion phenomenon in the sink hole, which is infiltration of 
Block scheme of condition analysis of the lake-basin system and optimizing measures justification

\begin{tabular}{|c|c|}
\hline $\begin{array}{l}\text { Main directions of LBS } \\
\text { condition evaluation and } \\
\text { operation optimization }\end{array}$ & Essence of research, evaluation and optimizing measures \\
\hline $\begin{array}{l}\text { Inventory of the lakes lo- } \\
\text { cated in the national parks } \\
\text { and condition evaluation } \\
\text { thereof }\end{array}$ & $\begin{array}{l}\text { - justification (choice) of criteria of lake condition evaluation; } \\
\text { - collection of information about the lake condition (archive information and } \\
\text { present one - data on the lake morphology, their origin, geological- } \\
\text { geomorphologic structure, about the aquatic complexes of the lake, its hy- } \\
\text { drochemistry and hydro-ecological condition); } \\
\text { - analysis of the collected information about the lake condition, systematiza- } \\
\text { tion and generalization thereof; } \\
\text { - lake condition evaluation (components and aquatic complexes as a whole). }\end{array}$ \\
\hline $\begin{array}{l}\text { Condition evaluation of } \\
\text { water catchment basins of } \\
\text { the lakes located in the na- } \\
\text { tional parks }\end{array}$ & $\begin{array}{l}\text { - collection of information about the catchment, analysis, systematization and } \\
\text { generalization thereof; } \\
\text { - evaluation of the catchment condition (based on the analysis of the land re- } \\
\text { serve structure, kinds of economic impact on the landscape catchment sys- } \\
\text { tems, ratio of the lands stabilizing and those destabilizing the environmen- } \\
\text { tal situation, and the similar). }\end{array}$ \\
\hline $\begin{array}{l}\text { Identification of the degree } \\
\text { of water catchment surface } \\
\text { being affected by negative } \\
\text { processes }\end{array}$ & $\begin{array}{l}\text { - } \text { erosive; } \\
\text { - deflationary; } \\
\text { - waterlogging; } \\
\text { - reduction of the productivity of agricultural lands; } \\
\text { - pollution of soil and vegetation cover, surface water and ground water. }\end{array}$ \\
\hline \multirow{2}{*}{$\begin{array}{l}\text { Identification of risks of } \\
\text { nature management in LBS }\end{array}$} & $\begin{array}{l}\text { in the aquatic complex: } \\
\text { - identification of risks of pollution and eutrophication of the lake; } \\
\text { - identification of risks of reduction of the lake biological productivity; } \\
\text { - identification of risks of change of the lake biodiversity. } \\
\text { - identification of risks of ecological condition deterioration }\end{array}$ \\
\hline & $\begin{array}{l}\text { at the catchment: } \\
\text { - identification of risks of deterioration of the catchment ecological condition; } \\
\text { - identification of risks of reduction of biotic and landscape diversity; } \\
\text { - identification of risks of development of negative processes on the catch- } \\
\text { ment surface (erosive; deflationary, melioration, and the similar). }\end{array}$ \\
\hline $\begin{array}{l}\text { Justification of the } \\
\text { measures aimed at im- } \\
\text { provement of LBS envi- } \\
\text { ronment condition }\end{array}$ & $\begin{array}{l}\text { - measures for optimization of hydro-ecological situation; } \\
\text { - measures for optimization of agro-ecological situation; } \\
\text { - measures for optimization of bio-ecological situation; } \\
\text { - measures for optimization of landscape-ecological situation in LBS; } \\
\text { - measures for optimization nature management. }\end{array}$ \\
\hline
\end{tabular}

Morphometric and hydrological characteristics of the lake Zasvitske

\begin{tabular}{|c|c|c|c|c|c|c|c|c|c|}
\hline $\begin{array}{c}* F, \\
\mathrm{~km}^{2}\end{array}$ & $\begin{array}{c}H_{\text {abs., }} \\
\mathrm{m}\end{array}$ & $\begin{array}{c}h_{\text {mid., }} \\
\mathrm{m}\end{array}$ & $\begin{array}{c}h_{\text {max., }} \\
\mathrm{m}\end{array}$ & $\begin{array}{c}\mathrm{L}, \\
\mathrm{km}\end{array}$ & $\begin{array}{c}W_{\text {max., }} \\
\mathrm{km}\end{array}$ & $\begin{array}{c}W_{\text {mid., }} \\
\mathrm{km}\end{array}$ & $\begin{array}{c}l, \\
\mathrm{~km}\end{array}$ & $C_{t .}$ & $C_{\text {len. }}$ \\
\hline 0,22 & 138,6 & 12,70 & 16,0 & 0,62 & 0,48 & 0,35 & 1,74 & 0,59 & 1,77 \\
\hline$C_{\text {cap. }}$ & $C_{\text {op. }}$ & $C_{\text {dep. }}$ & $\begin{array}{c}V_{\text {lake. }} \\
\text { thousand } \\
\mathrm{m}^{3}\end{array}$ & $A$ & $\begin{array}{c}\Delta S, \\
\mathrm{~km}^{2}\end{array}$ & $\begin{array}{c}W_{\text {influx }}{ }^{*} \\
\text { thousand } m^{3}\end{array}$ & $a_{\text {wat. }}$ & $\begin{array}{c}\Delta a_{\text {wat., }} \\
\mathrm{mm}\end{array}$ & $\begin{array}{c}A_{\text {layer }} \\
\mathrm{mm}\end{array}$ \\
\hline 0,79 & 0,02 & 21,17 & 5045,60 & 0,31 & 3,23 & 89562,24 & 17,75 & 0,06 & 7106,48 \\
\hline
\end{tabular}

*Area $(F)$; absolute height of the water level $\left(H_{a b s .}\right)$; maximum $\left(h_{\max .}\right)$ and average depth $\left(h_{\text {mid. }}\right)$; length $(L)$; maximum width $\left(W_{\max }\right)$; length of the shoreline $(l)$; coefficients: of shoreline unevenness $\left(C_{t}\right)$; of the lake lengthening $\left(C_{\text {len. }}\right)$; of capacity $\left(C_{c a p}.\right)$; of openness $\left(C_{o p}.\right)$; of depth $\left(C_{d e p}.\right)$; lake volume $\left(V_{\text {lake }}\right)$; area index $(A)$; specific catchment $(\triangle S)$; volume of inflow water from the catchment $\left(W_{\text {influx }}\right)$; conditional water exchange $\left(a_{\text {wat }}\right)$; specific water exchange $\left(\Delta a_{\text {wat. }}\right)$; water storage level on the catchment surface $\left(A_{\text {layer }}\right)$. $* *$ The average annual runoff module, $\mathrm{dm}^{3} / \mathrm{s} \mathrm{km}^{2}-4.0$. 
underground horizon water and its mixing with the lake water. The lake is closed.

Sampling of water from the lake Zasvitske for hydrochemical analysis showed that in terms of the block of indicators of salt composition of water (A), the results conform to MAC for fishery water bodies, in terms of trophicity and saprobity biological parameters (B) they also conform to standard indicators, except for $\mathrm{BOD}_{5}$, exceeding MAC by $0.85 \mathrm{mg}$ $\mathrm{O}_{2} / \mathrm{dm}^{3}$ (level of MAC exceedance in terms of hygienic classification of water bodies is allowable) (table 3). In terms of the block of toxic impact indicators (C) we observe MAC exceedance in the lake water only of copper and zinc (table 3 ).

Hydrochemical indices of the lake Zasvitske (as of 04/04/2016)

\begin{tabular}{|c|c|c|c|}
\hline $\begin{array}{c}\text { Serial } \\
\text { No }\end{array}$ & Index & MAC* & $\begin{array}{c}\text { Results of } \\
\text { measurements }\end{array}$ \\
\hline \multicolumn{4}{|c|}{ A. Indicator of salt composition } \\
\hline 1 & Mineralization (dry residue), $\mathrm{mg} / \mathrm{dm}^{3}$ & $<300$ & 112 \\
\hline 2 & Chloride ions, $\mathrm{mg} / \mathrm{dm}^{3}$ & 300 & 26.6 \\
\hline 3 & Sulphates, $\mathrm{mg} / \mathrm{dm}^{3}$ & 100 & 27.2 \\
\hline \multicolumn{4}{|c|}{ B. Tropho-saprobiological indicators } \\
\hline 1 & Suspended substance, $\mathrm{mg} / \mathrm{dm}^{3}$ & 25 & 10.58 \\
\hline 2 & Transparency, $\mathrm{m}$ & $>1.5$ & 3.2 \\
\hline 3 & $p H$ & $6.5-8.1$ & 7.14 \\
\hline 4 & $\mathrm{NH}_{4}^{+}, \mathrm{mg} \mathrm{N} / \mathrm{dm}^{3}$ & 0.5 & 0.00 \\
\hline 5 & $\mathrm{NO}_{3}^{-}, \mathrm{mg} \mathrm{N} / \mathrm{dm}^{3}$ & 40 & 0.375 \\
\hline 6 & $\mathrm{NO}_{2}^{-}, \mathrm{mg} \mathrm{N} / \mathrm{dm}^{3}$ & 0.08 & 0.06 \\
\hline 7 & $\mathrm{PO}_{4}^{3-},{\mathrm{mg} \mathrm{P} / \mathrm{dm}^{3}}^{3}$ & 2.14 & 0.17 \\
\hline 8 & Dissolved oxygen, $\mathrm{Mz}_{2} \mathrm{O}_{2} / \mathrm{dm}^{3}$ & $\geq 6$ & 10.4 \\
\hline 9 & $\%$ of saturation & $>85$ & Not determined \\
\hline 10 & $\mathrm{BOD}_{5}, \mathrm{mg} \mathrm{O}_{2} / \mathrm{dm}^{3}$ & 3 & 3.85 \\
\hline \multicolumn{4}{|c|}{ C. Specific indicators of toxic impact } \\
\hline 1 & Copper, $\mathrm{mg} / \mathrm{dm}^{3}$ & $0.001-0.01$ & 0.0035 \\
\hline 2 & Zinc, $\mathrm{mg} / \mathrm{dm}^{3}$ & 0.01 & 0.031 \\
\hline 3 & Cadmium, $\mathrm{mg} / \mathrm{dm}^{3}$ & 0.005 & 0.0013 \\
\hline 4 & Cobalt, $\mathrm{mg} / \mathrm{dm}^{3}$ & 0.01 & 0.0033 \\
\hline 5 & Mangan, $\mathrm{mg} / \mathrm{dm}^{3}$ & 0.01 & 0.0025 \\
\hline 6 & Lead, $\mathrm{mg} / \mathrm{dm}^{3}$ & 0.01 & 0.0018 \\
\hline 7 & Iron, $\mathrm{mg} / \mathrm{dm}^{3}$ & 0.1 & 0.1 \\
\hline
\end{tabular}

*Maximum Allowable Concentrations (MAC) of harmful substances for fishery water bodies [34].

Bottom sediments are represented by organomineral matter in the form of the lake sapropels. Maximum sapropel thickness (according to the data provided by Kyiv Geological Survey Expedition) of the lake Zasvitske is $6.5 \mathrm{~m}$, and the average one is $2.22 \mathrm{~m}$. The stock of sapropels is $116.3 \mathrm{~m}^{3}$ at natural moisture level of $90.6 \%$ (according to $\mathrm{C}_{2}$ category), and, recalculated at conditional $60.0 \%$ humidity amounts to 28.7 thousand tons. Pelogenous thickness is $0.2-0.3 \mathrm{~m}$; it is mainly concentrated in the littoral zone of the lake. Geochemical analysis of bottom sediment samples at one of the sounding sites located at the western part of the lake showed that concentration of iron compounds $\left(\mathrm{Fe}_{2} \mathrm{O}_{3}\right)$ in the samples (in \% on a dry-matter basis) is in the range from $0.62(10.5-11.0 \mathrm{~m})$ to 1.16 $(15.5-16.0 \mathrm{~m})$, and the concentration of calcium compounds $(\mathrm{CaO})$ varies from 0.37 (11.5-12.0 m) to $1.66(15.5-16.0 \mathrm{~m})$. Acidity index $(p H$ saline $)$ of sapropels ranges from weakly acidic reaction (5.43 - one sample) to neutral reaction (6.08-6.35) (fig.4).

Field, laboratory and remote investigation of the components of the lake landscape system served as a basis for compilation of the digital landscape map of the lake. Based on the methodology [23], NAC of the lake Zasvitske is considered as a complex aquatic tract in the morphological landscape structure. We have distinguished three subtracts within the limits of this aquatic tract, in particular: littoral, sublittoral profundal and profundal ones. As a result of more detailed landscape differentiation, we have distinguished several kinds of aquafacies in each subtract (fig. 5).

I. Littoral subtract on alluvial sand and clayey-sandy deposits with lenses of organicsandy sapropels and a variety of floating and subaqueous macrophytes.

Aquafacies: 1.1. Littoral, abrasion-accumulati- 


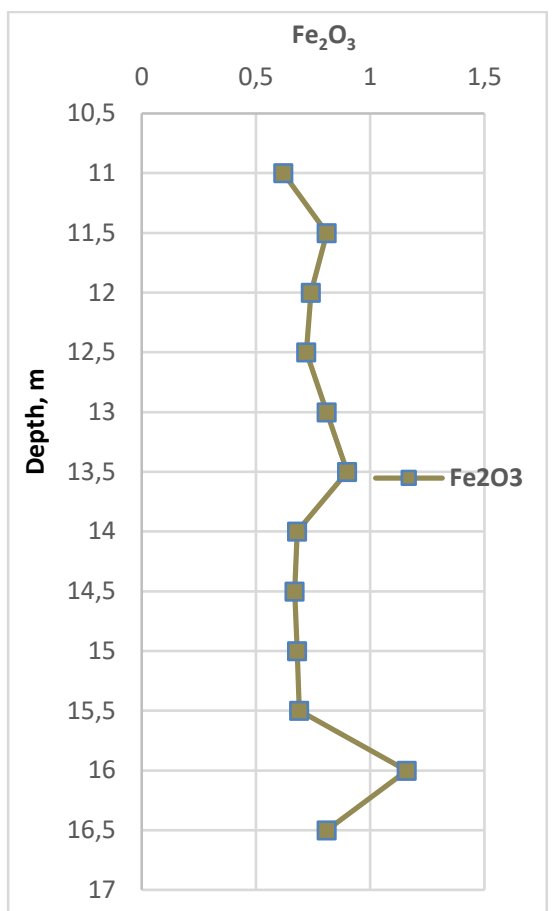

Distribution of $\mathrm{Fe}_{2} \mathrm{O}_{3}(\%$ on a drymatter basis) in bottom sediments

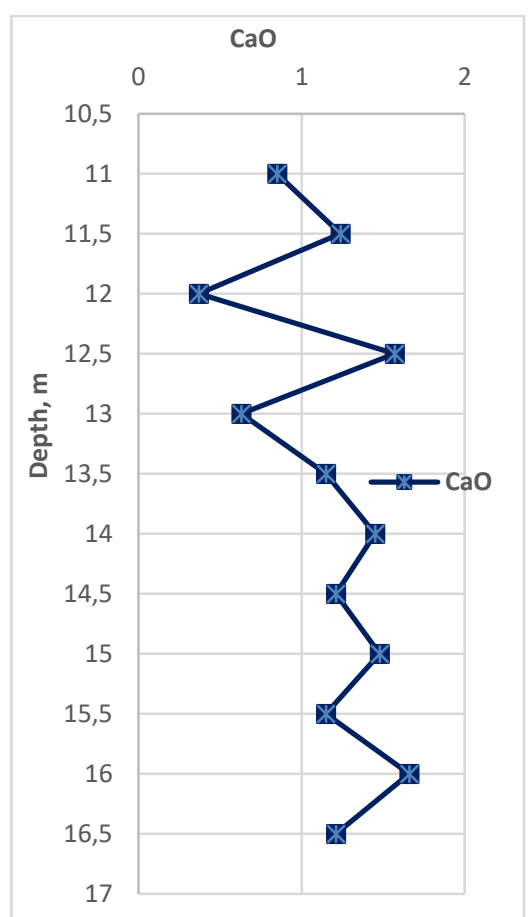

Distribution of $\mathrm{CaO}$

(\% on a dry-matter basis) in bottom sediments

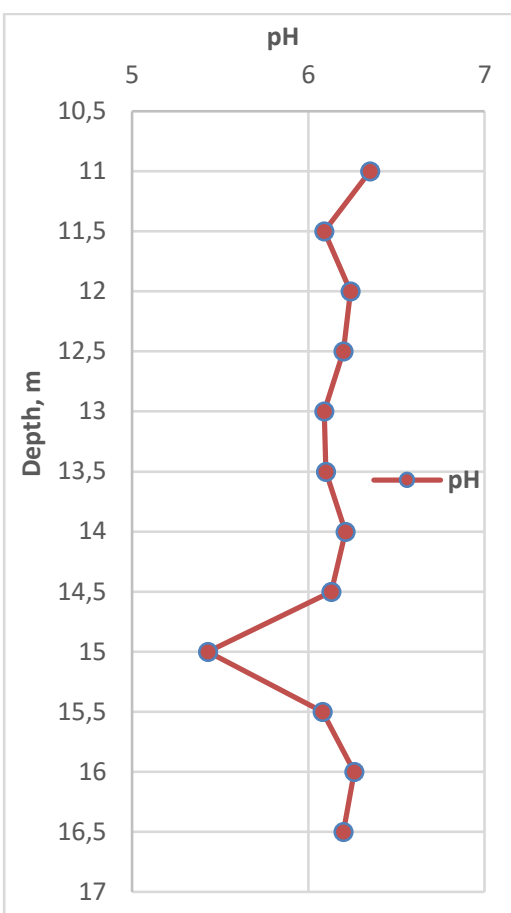

$\mathrm{Ph}$ distribution (salt extraction) in bottom sediments

Fig. 4. Geochemical features of bottom sediments of the lake Zasvitske (the graphical charts are based on the materials of Kyiv Geological Survey Expedition)

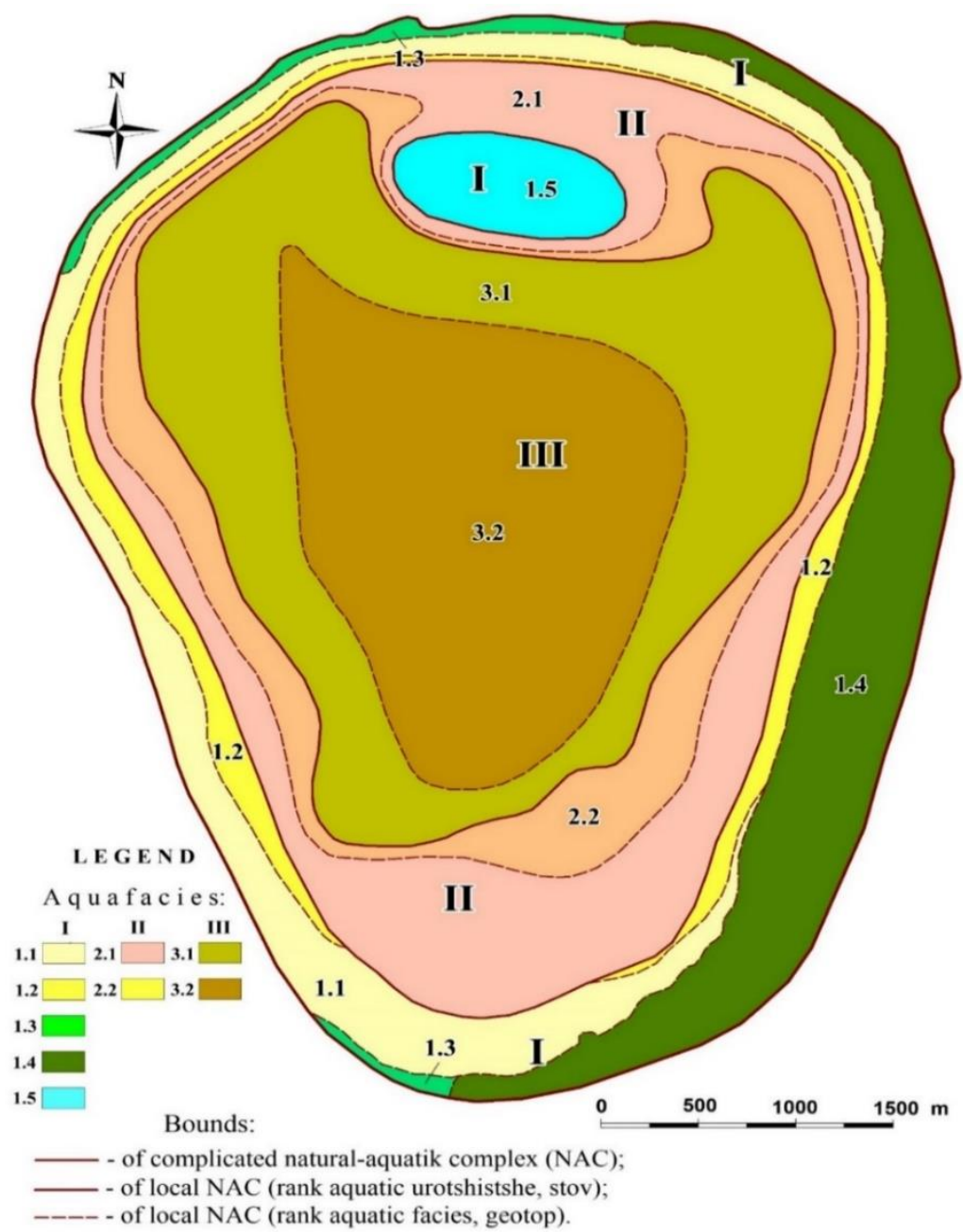

Fig. 5. Landscape map of the natural aquatic complex of the lake Zasvitske 
ve sandy, sedge-cattail, with no temperature stratification. 1.2. Littoral, abrasion-accumula-tive sandyclayey, sedge-reed, with no temperature stratification. 1.3. Littoral, accumulative clayey-sandy, cattail-reed and water lily-waterweed with no temperature stratification. 1.4. Littoral, abrasion-accumulative terrigenous-sandy-clayey-pelitic with lens of organic-sandy sapropels, reed-cattail-sedge, with no temperature stratification. 1.5. Littoral, of submerged-insular-elevation, transitional-accumula-tive sandy-clayey, sedge-cattail, with no temperature stratification.

II. Sublittoral-profundal subtract on organic-silicate sapropels formed on alluvial sand.

Aquafacies: 2.1. Sublittoral, transitionalaccumulative, organic-sandy, sapropel, moderately thick (3.5-5.0 m), pondweed-charophytic, with seasonal temperature non-uniformity $\mathbf{2 . 2}$. Sublittoral, accumulative-transitional, diatomic-sandy, sapropel, thick (5.0-6.5 m), with fully submerged water vegetation, with seasonal temperature non-uniformity.

III. Profundal subtract on carbonateferruginous sapropels formed on the upper cretaceous deposits of the Turonian Stage.

Aquafacies: 3.1. Profundal, transitional-accumumulative, clayey-limestone, sapropels, shallow (up to $2.5 \mathrm{~m}$ ), with single floating algae and seasonal temperature stratification. 3.2. Profundal, accumulative, organic-ferruginous, sapropel, moderately sick
(2.5-5.0 m) of basin bed deepenings, with scarcity of specific vegetation and vividly expressed seasonal temperature stratification.

The largest area in NAC of the lake Zasvitske is covered by the profundal subtract (above 42\%). Two types of aquafacies are distinguished in this subtract according to heterogeneity of species composition and thickness of sapropels, bathymetrical peculiarities of the lake basin, as well as according to pronounced seasonal temperature stratification. The littoral subtract $(30.80 \%)$ is distinguished by species diversity of aquafacies and the largest number of landscape units (6 pcs.).

This subtract serves as a peculiar ecological buffer for penetration of chemical substances from the catchment. The southern part of the lake aquatic area with the biggest variety of macrophytes and submerged vegetation communities is affected by the greatest impact of biogenic substances. The sublittoral-profundal subtract takes the intermediate position and covers the smallest area (about 26.5\%); there are two kinds of aquafacies distinguished there.

The aquafacie of submerged-insular elevation is situated in the northern part of NAC; it is located in sublittoral-profundal subtract, but belongs (according to geomorphological-lithological criteria) to the littoral subtract. The complexity of NAC territorial differentiation is shown in more details in table 4.

The complexity of NAC territorial structure of the lake Zasvitske

\begin{tabular}{|c|c|c|c|c|c|c|c|c|c|c|c|}
\hline \multicolumn{2}{|c|}{ NAC type } & \multicolumn{2}{|c|}{$\begin{array}{c}\text { Area }(S) \text { of NAC } \\
\text { type, ha }\end{array}$} & \multicolumn{2}{|c|}{$\begin{array}{l}\% \text { of the type } \\
\text { area from the } \\
\text { total area }\end{array}$} & \multirow{2}{*}{ 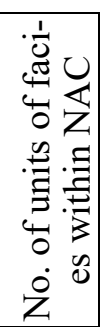 } & \multirow{2}{*}{ 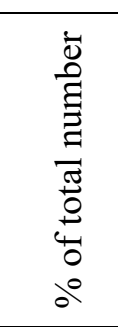 } & \multirow{2}{*}{ 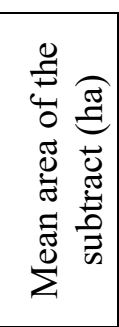 } & \multirow{2}{*}{ 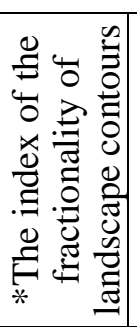 } & \multirow{2}{*}{ 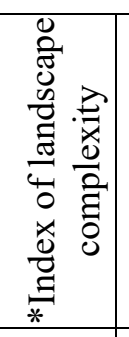 } & \multirow{2}{*}{ 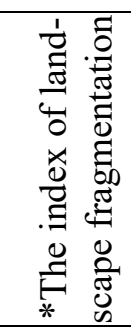 } \\
\hline \multirow{2}{*}{ Subtract } & \multirow{2}{*}{$\begin{array}{l}\text { Aqua- } \\
\text { facies }\end{array}$} & \multirow[t]{2}{*}{ Subtract } & \multirow{2}{*}{$\begin{array}{l}\text { Aqua- } \\
\text { facies }\end{array}$} & \multirow{2}{*}{ Subtract } & \multirow{2}{*}{$\begin{array}{l}\text { Aqua- } \\
\text { facies }\end{array}$} & & & & & & \\
\hline & & & & & & $n$ & $\%$ & $\begin{array}{c}S_{0}= \\
S / n\end{array}$ & $\begin{array}{c}I_{f . c .}= \\
n / S\end{array}$ & $\begin{array}{c}I_{\text {l.c. }}= \\
n / S_{0}\end{array}$ & $\begin{array}{l}I_{l . f .}= \\
1-S_{0} / S\end{array}$ \\
\hline \multirow[t]{6}{*}{ I } & & 6.817 & & 30.80 & & 6 & 60.00 & 1.136 & 0.880 & 5.282 & 0.833 \\
\hline & 1.1 & & 2.085 & & 9.42 & & & & & & \\
\hline & 1.2 & & 1.127 & & 5.09 & & & & & & \\
\hline & 1.3 & & 0.281 & & 1.27 & & & & & & \\
\hline & 1.4 & & 2.762 & & 12.48 & & & & & & \\
\hline & 1.5 & & 0.562 & & 2.54 & & & & & & \\
\hline \multirow[t]{3}{*}{ II } & & 5.862 & & 26.49 & & 2 & 20.00 & 2.931 & 0.341 & 0.682 & 0.500 \\
\hline & 2.1 & & 3.616 & & 16.34 & & & & & & \\
\hline & 2.2 & & 2.246 & & 10.15 & & & & & & \\
\hline \multirow[t]{3}{*}{ III } & & 9.452 & & 42.71 & & 2 & 20.00 & 4.726 & 0.212 & 0.423 & 0.500 \\
\hline & 3.1 & & 5.207 & & 23.53 & & & & & & \\
\hline & 3.2 & & 4.245 & & 19.18 & & & & & & \\
\hline \multicolumn{2}{|c|}{ Total } & 22.131 & 22.131 & 100.00 & 100.00 & 10 & 100.00 & 2.213 & 0.452 & 4.519 & 0.900 \\
\hline
\end{tabular}

*Indices and coefficients were calculated according to the formulas proposed by A. Viktorov [4]. 
The catchment subsystem takes an important place in the integral LBS. The hydroecological situation in the water body itself will also depend on the geoecological processes happening on the catchment. The catchment area of the lake Zasvitske is $0.71 \mathrm{~km}^{2}$. Cartometric evaluation of spatialtypological structure of the lake catchment showed that $56.34 \%$ of its area is covered by forests, the lands with open sand cover $1.41 \%$, slightly more than $11 \%$ are under road surface and about $31 \%$ are represented by the lake aquatic area. There are no swamped or plowed lands within the limits of the catchment. Economic development index of the catchment is $0.13 \%$. It is a very good indicator for a nature national park. The land structure in more details is outlined in table 5 .

The landscape map of the lake catchment that we compiled as the result of the field instrumental investigations is shown in fig. 6 .

Parameters of the catchment of the lake Zasvitske and the structure of its land

\begin{tabular}{|c|c|c|c|c|c|c|c|c|c|c|c|c|c|}
\hline \multirow{3}{*}{$\begin{array}{c}S, \\
\mathrm{~km}^{2}\end{array}$} & \multirow{3}{*}{$\begin{array}{c}P, \\
\mathrm{~km}^{2}\end{array}$} & \multirow{3}{*}{$m$} & \multicolumn{10}{|c|}{ Land area } & \multirow{3}{*}{$\begin{array}{c}\mathbf{S}_{a . l} / \\
\mathbf{S}_{\text {not c.l }} \\
\% \\
\end{array}$} \\
\hline & & & \multicolumn{2}{|c|}{$F_{\text {lake }}$} & \multicolumn{2}{|c|}{$f_{\text {forest }}$} & \multicolumn{2}{|c|}{$f_{\text {sands }}$} & \multicolumn{2}{|c|}{$f_{\text {arable lands }}$} & \multicolumn{2}{|c|}{$f_{\text {road coverage }}$} & \\
\hline & & & $\mathrm{km}^{2}$ & $\%$ & $\mathrm{~km}^{2}$ & $\%$ & $\mathrm{~km}^{2}$ & $\%$ & $\mathrm{~km}^{2}$ & $\%$ & $\mathrm{~km}^{2}$ & $\%$ & \\
\hline 0.71 & 3.58 & 0.68 & 0.22 & 30.98 & 0.40 & 56.34 & 0.01 & 1.41 & 0.00 & 0.00 & 0.08 & 11.27 & 0.13 \\
\hline
\end{tabular}

*Area of the catchment $(S)$, perimeter of the catchment $(P)$, coefficient of foreshore unevenness $(m)$, lake area $\left(F_{\text {lake }}\right)$, forest index $\left(f_{\text {forest }}\right)$, open sand $\left(f_{\text {sands }}\right)$, arable lands $\left(f_{\text {arable lands }}\right)$, road coverage $\left(f_{\text {road coverage. }}\right) ; \mathrm{S}_{\text {a.l }} / \mathrm{S}_{\text {not c.l }}($ arable land/not cultivated land), \% - indicator of economic development of the catchment.

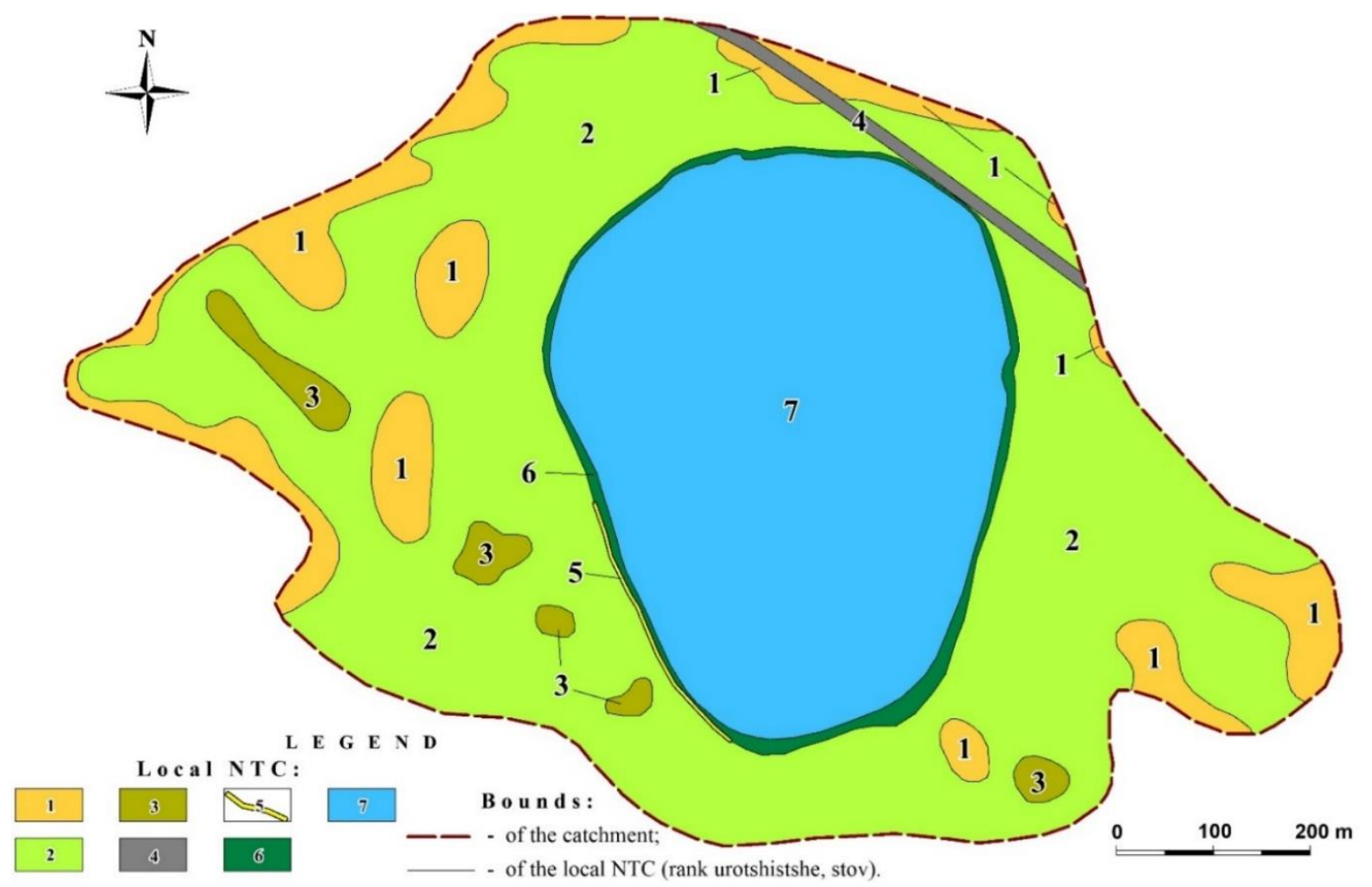

Fig. 6. Landscape structure of geocomplexes of the catchment of the lake Zasvitske

1. Sandy hills and dunes with gentle $\left(10-12^{\circ}\right)$ slopes, covered by lichenous- fruticulose and grasstrue moss pine forests on sod-cryptopodzol-rubblesandy and sandy loam soils. 2. Levelled and undulated sites, covered by bilberry-grass and lichenousbracken pine forests on sod-cryptopodzol and lowpodzol low-rubble eroded sandy and sandy loam soils. 3. Local hills with gentle slopes with weak (5$7^{\circ}$ ) sloping, covered by lichenous-true moss and lichenous- gramineous oak-birch-pine forests on lopodzolic rubble-sandy and sandy loam soils. 4. A highway with stone covering and low artificial embankments with grassy slopes covered by grassgramineous vegetation. 5. The lakeside sand bar, covered by pine-birch-alder small forest. $\mathbf{6}$. Lakeside narrow depressions, covered by mesophytic-gramineous-grass and cattail-sedge-true-moss, and pine-birch-willow small forest. 7. The lake kettle depression with an oval form, covered in the littoral zone by sedge-juncaceous-reed communities, 
and in the sublittoral and profundal ones by sparse floating and bottom algae on sapropels.

We have distinguished seven NTC of the tract rank within the limits of the catchment, including the aquatic tract of the lake Zasvitske. Nature complexes of the catchment are located at the highest orographical level and are confined to pine-forest terrace locality on alluvial aqueoglacial sandy clay, underlaid by chalky rocks.

The western part of the catchment is banded by the tracts of sandy hills and dunes $(k 1)$. They have local nature of spreading in the rest part. NTC of levelled and undulated sites $(k 2)$ of the basin system are dominant in area (more than 53\%). Open sands are locally spread on non-grassy sites in the western part of the catchment. The tracts of local hills $(k 3)$ comprise five landscape units and cover about $2 \%$ of the catchment area. There is a road with solid covering in the north-eastern part of the catchment $(k 4)$. Traffic intensity is very low, thus, anthropogenic influence from transport on the lake is miserable. The lake is bordered by lakeside depressions $(k 6)$ and a small sand bar $(k 5)$ in the south-western part of the catchment.

The provided indices of divisibility of the landscape outlines, the landscape complexity and the landscape fragmentation are important for comparison with other water bodies of the park being designed. The latter index is very informative and mainly depends on the number of outlines of NTC type $(n)$. If the number of landscape units rises, the average weighted area $\left(S_{0}\right)$ will be smaller, and the landscape fragmentation index $\left(I_{f . r}\right)$ will be approaching 1 , in other words, to its maximum. At the same time, if $n=1$, the coefficient $I_{f, r}$. will turn to zero. Complexity of territorial differentiation of NTC of the lake Zasvitske is provided in table 6. The characteristics and indices calculated will be included into the ecological passport of this lake.

Discussion of the results. In accordance with

Table 6

Complexity of territorial dissection of the catchment of the lake Zasvitske

\begin{tabular}{|c|c|c|c|c|c|c|c|c|}
\hline 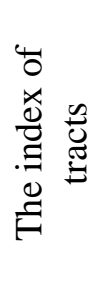 & 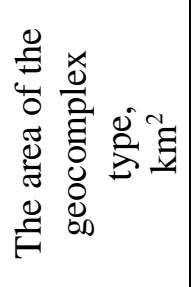 & 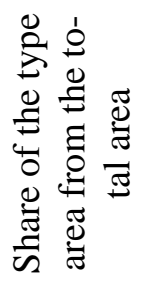 & 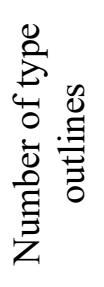 & 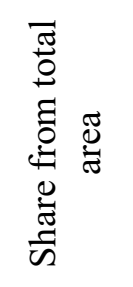 & 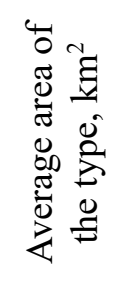 & 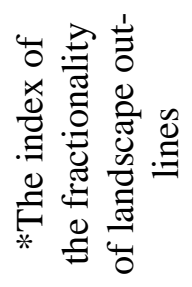 & 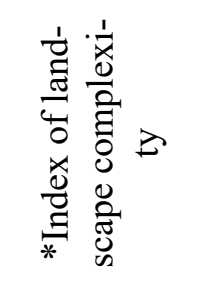 & 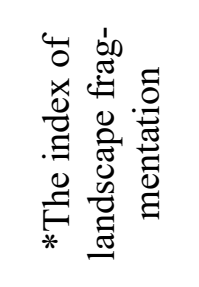 \\
\hline$k$ & $S$ & $\%$ & $n$ & $\%$ & $S_{0}$ & $I_{\text {f.c. }}=n / S$ & $I_{\text {l.c. }}=n / S_{0}$ & $I_{l . f .}=1-S_{0} / S$ \\
\hline 1 & 0.0733 & 10.36 & 10 & 47.62 & 0.0073 & 136.4256 & 1369.8630 & 0.9004 \\
\hline 2 & 0.3767 & 53.22 & 2 & 9.52 & 0.1884 & 5.3093 & 10.6157 & 0.4999 \\
\hline 3 & 0.0137 & 1.94 & 5 & 23.81 & 0.0027 & 364.9635 & 1851.85189 & 0.8029 \\
\hline 4 & 0.0064 & 0.90 & 1 & 4.76 & 0.0064 & 156.2500 & 156.25 & 0.0000 \\
\hline 5 & 0.0015 & 0.21 & 1 & 4.76 & 0.0015 & 666.6667 & 666.6667 & 0.0000 \\
\hline 6 & 0.0149 & 2.11 & 1 & 4.76 & 0.0149 & 67.1141 & 67.1141 & 0.0000 \\
\hline 7 & 0.2213 & 31.27 & 1 & 4.76 & 0.2213 & 4.5188 & 4.5188 & 0.0000 \\
\hline Total & 0.7078 & 100.00 & 21 & 100.00 & 0.0337 & 29.6694 & 623.1454 & 0.9524 \\
\hline
\end{tabular}

*Indices and coefficients were calculated according to the formulas of A. Viktorov [4].

the Law of Ukraine "On the Nature Reserve Fund", four functional zones are distinguished in the territories of NNP, in particular, a reserved zone, a zone of regulated recreation, a stationary recreation zone and an economic zone [8]. The basis for their selection are landscape maps created as a result of field and laboratory research, analysis of thematic maps (geological, soil, botanical, geochemical, hydrochemical) and the Earth remote sensing data. The use of our landscape-basin approach and the algorithm for investigating LBS, the landscape maps of LBS as a whole, and the maps of their naturalaquatic subsystems created for the first time, provide further possibilities for functional zoning of national parks with a high lake percentage, as well as for solving nature conservation problems and optimizing nature resource management. The electronic landscape maps that we compiled can be used as reference documents for further monitoring investigation of lakes and their basins. This task is extremely important under conditions of very intense climate changes both globally and regionally. This is evidenced by the results of researches carried out by scientists regarding the reaction of lakes to climate changes $[1 ; 20 ; 30 ; 41]$. Research prospects are seen in the more active use of Earth remote sensing data and LBS investigation using unmanned aerial vehicles, geoinformation-cartographic modelling of 
changes in their condition and justification of a complex of nature protection measures. Similar in the content research is being also conducted in the foreign countries $[5 ; 21 ; 32]$, which confirms the relevance, scientific and practical significance of LBS research.

\section{CONCLUSION}

1. The research resulted in justification of the essence of basin-landscape approach to LBS investigation and informational and analytical provision for protection of the lakes of the national natural parks, as the direction, being formed at the interface of environmental landscape science, hydrology, constructive geography and geoecology. We revealed the peculiarities and proposed the block scheme (algorithm) of analysis and evaluation of the ecological condition of the lake-basin system (LBS) located in the territory of the nature reserve, and specified the steps to justify the measures aimed at optimizing its condition.

2. Based on field landscape and hydrological, limnologic and geographical research of Zasvitske lake-basin system, cross-section and longitudinal profiles of the lake have been composed for the first time, as well as its bathymetrical map (in scale 1:5000), the landscape map of the lake and the whole LBS. We have obtained data on hydroecological condition of the water body, and on negative geomorphologic processes unfolding on the surface of the lake catchment. These data serve as informationalanalytical base for further monitoring of ecological condition of LBS, planning of measures, aimed at conservation of the nature reserved site and improvement of its operation.

3. The characterised approach to studying nature-protected lake-basin systems, which combines cartometric, field landscape-geographical, hydrological-hydrochemical, geoecological researches and mapping, analysis of space images, fund materials of geological-searching works, and other information, can be applied while investigating lakebasin systems not only in the nature reserve areas, but also in the regions utilized long ago. The results obtained are of interest while solving the tasks of water and soil cadastre, introducing a passport system for water bodies with low water exchange, solving geoecological, nature-protecting and land use planning tasks.

\section{Bibliography}

1. Benateau S. Climate change and freshwater ecosystems: Impacts on water quality and ecological status. HydroCH2018 Project. Federal Office for the Environment (FOEN) / S. Benateau, A. Gaudard, C. Stamm, F. Altermatt. Bern, Switzerland, 2019. - P. 110. DOI: https://doi.org/10.5167/uzh-169641

2. Булатов В. И. Ландшафтно-экологический и картографический анализ озерно-бассейновых систем юга Западной Сибири (озера Чаны и Колундинское) / В.И. Булатов, И.Н. Ротанова, Д.В. Черных // Сибирский экологический журнал. - 2005. - № 2. - C. 175-182.

3. Wetzel R. A. Limnological analysis [Text] : monograph / R.A Wetzel, G.E. Likens. 2nd ed. - New York [et al.] : Springer, 1991. - P. 391.

4. Викторов А. С. Рисунок ландшафта: анализ геометрических свойств ландшафта и его практическое применение. Изд. 2-е. - М. : ЛЕНАНД, 2014.

5. Dawidek J. The role of catchment and in-lake processes in shaping trophic conditions of the shallow lake Syczynskie (Eastern Poland) / J. Dawidek, W. Peczula, B. Ferencz // Ecohydrology and Hydrobiology. - 2009. - № 2-4. - Pp. 193-200. DOI: https://doi.org/10.2478/v10104-010-0011-2

6. DIRECTIVE 2000/60/EC of the European Parliament and of the council of 23 October 2000 establishing a framework for Community action in the field of water policy. - Pежим достуny: http:/leurlex.europa.eu/resource.html? uri=cellar:5c835afb-2ec6-4577-bdf8-756d3d694eeb.0004.02/DOC $1 \&$ format $=$ PDF

7. Эдельштейн К. К. Лимнология: учеб. пособие для бакалавриата / К.К. Эдельштейн. 2-е изд. - М. : Изд-во Юрайт, 2017. - 398 c.

8. Закон Украӥни «Про природно-заповідний фонд Украӥни» // Відомості Верховної Ради Украӥни (ВВР). - 1992. - № 34. - C. 502.

9. Ільїн Л. В. Лімнокомплекси Украӥнського Полісся : монографія : У 2-х m. Т.1: Природничо-географічні основи дослідження та регіональні закономірності / Л.В. Ільїн. - Луиььк : РВВ «Вежа» Волин. нац. ун-ту імені Лесі Українки, 2008. - 316 с.

10. Ільїн Л. В. Лімнокомплекси Українського Полісся : монографія : У 2-х m. Т.2: Регіональні особливості та оптимізація / Л.В. Ільӥн. - Луиьк : РВВ «Вежа» Волин. нац. ун-ту імені Лесі Українки, 2008. - 400 с.

11. Ковальчук А. І. Атласне картографування річково-басейнових систем: монографія / А.І. Ковальчук, І.П. Ковальчук ; за наук. ред. проф. І.П. Ковальчука. - Львів : Простір-М, 2018. - 348 с.

12. Ковальчук I. П. Регіональний еколого-геоморфологічний аналіз / І.П. Ковальчук. - Львів : Вид-во Ін-ту украйнознавства, 1997. - $440 \mathrm{c.}$.

13. Ковальчук I. П. Водні ресурси, гідрологічний режим річок та озер в регіональному ландшафтному парку Прип'ять-Стохід / І.П. Ковальчук // Гідрологія, гідрохімія та гідроекологія. - Київ: Ніка-центр, 2001. - Т. 2. -C. 323-334.

14. Ковальчук І. П. Управління водогосподарською та водоохоронною діяльністю (на прикладі басейну Західного Бугу) / І.П. Ковальчук // Український географічний журнал. - 2009. - № 3. - С. 49-53. 
15. Ковальчук I. П. Геоінформаџійне атласне картографування озерно-басейнових систем / I.П. Ковальчук // Наук. зап. Тернопільс. держ.-го пед.-го ун-ту. Сер. Географія. - 2014. - № 1. - С. 176-182.

16. Ковальчук I. П. Ландшафтознавчо-лімнологічний аналіз озерно-басейнової системи (на прикладі озера Ніговище) / I. П. Ковальчук, В. О. Мартинюк // Украйнський географічний журнал. - 2013. - № 2. - С. 60-66. https://doi.org/10.15407/ugz2013.02.060

17. Kovalchuk I. P. Methodology and experience of landscape-limnological research into lake-basin systems of Ukraine / I.P. Kovalchuk, V.A. Martyniuk // Geography and Natural Resources. - 2015. - Vol. 36. - Issue 3. - Pp. 305-312. https://doi.org/10.15407/ugz2013.02.060

18. Ковальчук I. Конструктивно-географічні дослідження озерно-басейнових систем для потреб збалансованого природокористування / I. Ковальчук, В. Мартинюк // Украӥнська географія: сучасні виклики. 3б. наук. праць у 3-х т. - К. : Прінт-Сервіс, 2016. - T. 2. - С. 128-130.

19. Корытный Л. М. Бассейновая концеепция в природопользовании / Л.М. Корытный. - Иркутск : Изд-во Ин-та географии СО РАH, 2001. - 163 c.

20. Landkildehus F. Climate change effects on shallow lakes: design and preliminary results of a cross-European climate gradient mesocosm experiment / F. Landkildehus, M. Søndergaard, M. Beklioglu [at. el.] // Estonian J. of Ecology. - 2014. - № 63(2). - Pp. 71-89. http://dx.doi.org/10.3176/eco.2014.2.02

21. Liu X. Landscape Pattern Changes in the Xingkai Lake Area, Northeast China / X. Liu, Y Zhang, G. Dong, G. Hou, M. Jiang // Int J Environ Res Public Health. 2019. - № 16(20), 3820. DOI: https://doi.org/10.3390/ijerph16203820

22. Лопух П. С. Общая лимнология. Курс лекиий / П. С. Лопух, О.Ф. Якушко. - Минск : Изд-во БГУ, $2011 .-340$ с.

23. Мартинюк В. О. Ландшафтно-лімнологічний аналіз басейнової (озерної) геосистеми / В. О. Мартинюк // Наук. зап. Тернопіл. держ-го пед. ун-ту. Сер. Географія. - 1999. - № 2. - C. 29-36.

24. Martynyuk V. Constructive geographical model of the lake-basin specialized recreational system (on the example of the lake Ostrivske, Ukrainian Polesia) / V. Martynyuk // J of Wetlands Biodiversity. - 2015. - Vol. 5. - Pp. $115-126$.

25. Мартинюк В. О. Регіональне ландшафтно-гідрографічне ГІС-моделювання поверхневих вод Полісся / В. О. Мартинюк // Прыроднае асяроддзе Палесся: асаблівасиі і перспектывы развічия : зб. навук. праи. - Брэст: Альтернатива, 2018. - Bыn. 11. - С. 70-73.

26. Мартинюк В. О. Гідрографічні особливості поверхневих вод Верхньоприп'ятського фізико-географічного району (Волинське Полісся) / В. О. Мартинюк // Наук. вісник Херсон. держ-го ун-ту. Серія: Географ. науки. 2019. - Bun. 11. - C. 114-123. DOI: https://doi.org/10.32999/ksu2413-7391/2019-11-15

27. Martyniuk V. O. Regional constructive geographical modeling of lake-basin systems of Ukraine / V.O. Martyniuk, S.V. Andriichuk, I.V. Zubkovych // The development of nature sciences: problems and solutions: Conference Proceedings, April 27-28, 2018. - Brno: Baltija Publishing. - P. 218-222.

28. Martyniuk V. The landscape-lymnological analysis of the key land «Ostrivsky lakes» (Nobel national park, Ukraine) / V. Martyniuk, I. Zubkovych // New stages of development of modern science in Ukraine and EU countries: monograph / edited by authors. 7th ed. - Riga, Latvia : "Baltija Publishing”, 2019. - Pp. 238-263. DOI: https://doi.org/10.30525/978-9934-588-15-0-140

29. Мельник А. В. Ландшафтний моніторинг / А.В. Мельник, Г.П. Міллер. - К. : ІСДО, 1993. - 152 c.

30. Mooij W. M. The impact of climate change on lakes in the Netherlands: a review / W.M. Mooij, S. Hülsmann, L.N. De Senerpont Domis [et al.] // Aquatic Ecology. - 2005. - № 39. - Pp. 381-400. DOI: http://dx.doi.org/ 10.1007/s10452-005-9008-0

31. Nazarova T. Landscape and limnological research of lake system of the plain areas of the northeastern borderlands of the Republic of Kazakhstan and assessment of their recreational capacity / T. Nazarova, I. Fomin, P. Dmitriyev [et al.] // Geojournal of Tourism and Geosites. - 2019. - № 25. - Pp. 485-495. http://dx.doi.org/ 10.30892/gtg.25217-375

32. Pasztaleniec A.The Ecological Status of Lakes in National and Landscape Parks: Does the Location of a Lake and Its Catchment within a Protected Area Matter? / A. Pasztaleniec, S. Kutyta // Pol. J. Environ. Stud. - 2015. - № 24 (1). - Pp. 227-240. http://dx.doi.org/10.15244/pjoes/24926

33. Пересадько В. А. Географічне моделювання наиіональних природних парків / В.А. Пересадько, О.В. Бодня. Харків, 2010. - 28 c.

34. Перечень рыбохозяйственных нормативов предельно допустимых концентраций (ПДК) и ориентировочно безопасных уровней воздействий (ОБУВ) вредных веществ для водных объектов, имеющих рыбохозяйственное значение. - М. : Изд-во ВНИРО, 1999.

35. Robertson D. M. Water-quality response to changes in phosphorus loading of the Winnebago Pool Lakes, Wisconsin, with special emphasis on the effects of internal loading in a chain of shallow lakes / D.M. Robertson, B.J. Siebers, M.W. Diebel, A.J. Somor // U.S. Geological Survey Scientific Investigations Report 2018-5099, 58. DOI: https://doi.org/10.3133/sir20185099

36. Руденко Л. Г. Методика оченивания территории для формирования сети заповедных объектов в Украине / Л.Г. Руденко, А.Г. Голубиов, В.М. Чехний [и др.] // Природопользование. - 2019. - № 1. - С. 37-50.

37. Самойленко В. М. Моделювання басейнових геосистем: Монографія / В.М. Самойленко, Д.В. Іванок. - К. : ДП «Прінт-Сервіс», 2015. - 208 с.

38. Сулік Л. Аналіз структури та геопросторового розподілу природно-заповідного фонду Волинського Полісся як важливої складової екотуристичного потенціалу регіону / Л. Сулік, Д. Кричевська // Вісн. Львів. ун-ту. Серія географ. - 2014. - № 47. - C. 273-280. 
39. Choiński A. Jeziora $w$ parkach narodowych, rezerwatach przyrody i parkach krajobrazowych Polski północnej $i$ środkowej / A. Choiński, A. Macias // Wody na obszarach chronionych. J. Partyka, J. Pociask-Karteczka (red.) / Instytut Geografii i Gospodarki Przestrzennej UJ, Ojcowski Park Narodowy, Komisja Hydrologiczna PTG. Kraków, 2008. - Pp. 31-42.

40. Управление трансграничным бассейном Днепра: суббассейн реки Припяти: монография; под ред. А.Г. Ободовского, А.П. Станкевича, С.А. Афанасьева. - К.: Кафедра, 2012. - 448 с.

41. Havens K. Ecological Responses of Lakes to Climate Change / K. Havens, E. Jeppesen // Water. - 2018. - № 10(7).917. DOI: http://dx.doi.org/10.3390/w10070917

Authors Contribution: All authors have made an equal contribution to this work.

UDC 911.5:502.13:502.51(285):556.55

Ivan Kovalchuk,

Doctor of Science (Geography), Professor, Head of the Department of Geodesy and Cartography,

National University of Life and Environmental Sciences of Ukraine,

17 Vasylkivska St., Building 6, Kyiv, 03040, Ukraine,

e-mail: kovalchukip@ukr.net, https://orcid.org/0000-0002-2164-1259;

\section{Vitalii Martyniuk,}

$\mathrm{PhD}$ (Geography), Associate professor, Professor at the Department of Ecology, Geography and Tourism,

Rivne State University of Humanities, 12 St. Bandery St., Rivne, 33028, Ukraine,

e-mail: martynyukVO@,gmail.com, http://orcid.org/0000-0002-8654-3510;

\section{Vaida Šeiriené,}

Doctor (Natural sciences), Senior researcher, Head of the Laboratory of Quaternary Research,

Nature Research Centre Institute of Geology and Geography, 2 Akademijos St., LT-08412, Vilnius, Lithuania, e-mail: vaida.seiriene@gamtc.lt, https://orcid.org/0000-0002-9477-2321

\section{THE BASIN-LANDSCAPE APPROACH TO THE PROTECTION AND CONDITION OPTIMIZATION OF THE LAKES OF THE NATIONAL PARKS}

The essence of the basin-landscape approach to the protection of the lakes of the national parks as an actual direction of research, which is formed at the junction of nature protection landscaping, hydrology and geoecology has been substantiated. The research algorithm, peculiarities of analysis and assessment of the status of the lake-basin system (LBS) have been found out, the factors that worsen the geo-ecological state in the lake and basin subsystems have been revealed, optimization measures in the objects of the nature reserve fund located within the natural reserve have been substantiated.

The purpose of the study is to determine the parameters of the structure of lake-basin landscapes (on the example of Zasvitske lake, Nobel National Natural Park, Ukraine), liminary and landscape-metric indicators of the geo-ecological status of the LBS and the factors influencing it as an information and analytical basis for ensuring the protection and management of the LBS located in nature conservation area.

The materials of the study were the long-term field landscape-limnological and geo-ecological studies of the authors within the Polesia region of Ukraine and, in particular, the LBS of the Nobel National Nature Park.

The research methodology was based on complex physical-geographical methods, hydrological profiling and creation of bathymetric models of reservoirs, hydrochemical diagnostics of water masses of the lakes, geochemical analyses of bottom sediments, landscape mapping using GIS-technologies.

The results of geo-ecological (landscape-ecological) researches of the lake-basin system of Zasvitske lake have been presented, in particular, original profiles and bathymetric model of the reservoir, landscape maps of the aqual complex and the lake catchment, limno- and landscape characteristics of the LBS have been shown. Considering the level of anthropogenic transformations of the LBS and the presence of a high proportion of ecologically-stabilizing lands (forests, reservoirs of natural origin), the level of sustainability of the LBS is estimated as high. An assessment of the hydrological characteristics of the reservoir and hydrochemical characteristics allows to attribute this lake to an oligotrophic type. The results of a comprehensive analysis of the geo-ecological parameters of the state of Zasvitske lake and its landscape-limnological functioning indicate the expediency of recreational specialization of nature management in the Nobel National Park, that includes this lake. 
Scientific novelty. The application of proposed landscape-basin approach and the algorithm of the LBS study increase the possibilities of functional zoning of national parks with high index of lakes, as well as solving the problems of nature protection and optimization of nature management.

Practical importance. The created electronic landscape maps and the base of limnometric parameters can be used as reference documents for the certification and cadastral evaluation of the transboundary protected areas of Ramsar type, geo-ecological monitoring and an integrated management of lakes by the basin approach in conditions of intense climate change.

Keywords: landscape, basin-landscape approach, lake-basin system, natural aqual complex, natural territorial complex, national park.

\section{References}

1. Benateau, S., Gaudard, A., Stamm, C. \& Altermatt, F. (2019). Climate change and freshwater ecosystems: Impacts on water quality and ecological status. Hydro-CH2018 Project. Federal Office for the Environment (FOEN), Bern, Switzerland, 110. https://doi.org/10.5167/uzh-169641

2. Bulatov, V.I., Rotanova, I.N., Chernyih, D.V. (2005). Landscape-ecological and cartographic analysis of lake-basin systems in the south of Western Siberia (lake Chanyi and Kolundinskoe). Sibirskiy ekologicheskiy zhurnal, 2, 175182.

3. Wetzel, R.A., Likens, G.E. (1991). Limnological analysis : monograph. 2nd ed. New York [et al.] : Springer, 391.

4. Viktorov, A.S. (2014). Landscape drawing: analysis of the geometric properties of the landscape and its practical use. Edit. 2-nd. Moscow: LENAND.

5. Dawidek, J., Peczula, W., Ferencz, B. (2009). The role of catchment and in-lake processes in shaping trophic conditions of the shallow lake Syczynskie (Eastern Poland). Ecohydrology and Hydrobiology, 9(2-4), 193-200. https://doi.org/10.2478/v10104-010-0011-2

6. DIRECTIVE 2000/60/EC of the European Parliament and of the council of 23 October 2000 establishing a framework for Community action in the field of water policy. (2020). Taken from: http://eurlex.europa.eu/resource.html?uri=cellar:5c835afb-2ec6-4577-bdf8-756d3d694eeb.0004.02/DOC 1\&format=PDF [in English]

7. Edelstein, K.K. (2017). Limnology: a textbook for undergraduate studies. 2-nd ed. M.: Yurayt Publishing House, 398.

8. Law of Ukraine "About the natural reserve fund of Ukraine». (1992). Information of the Verkhovna Rada of Ukraine (VVR), 34, 502.

9. Il'in, L.V. (2008a). Limnocomplexes of Ukrainian Polesia : Monograph: In 2 t. T. 1: Spatial and geographical bases of research and regional patterns. Lutsk: RVV "Vezha" VNU im. L. Ukrainka.

10. Il'in, L.V. (2008b). Limnocomplexes of Ukrainian Polesia: Monograph: In 2 t. T. 2: Regional features and optimization. Lutsk: RVV "Vezha" VNU im. L. Ukrainka.

11. Kovalchuk, A.I, Kovalchuk, I.P. (2018). The atlas mapping of river basin systems: monograph; for science ed. prof. I.I. Kovalchuk. Lviv: Prostir-M, 348.

12. Kovalchuk, I.P. (1997). Regional ecological-geomorphological analysis. Lviv: Publishing House of the Institute of Ukrainian Studies, 440.

13. Kovalchuk, I.P. (2001). Water resources, hydrologic regime of rivers and lakes in the regional Pripyat Stokhid landscape park. Hydrology, hydrochemistry and hydroecology. Sci. collection. Kyiv: Nika Center, 2, 323-334.

14. Kovalchuk, I.P. (2009). The guidance of water management and water protection activities (on the example of the basin of Western Bug). Ukrainian Geographical Journal, 3, 49-53.

15. Kovalchuk, I.P. (2014). Geoinformation atlas mapping of lake-basin systems. Sci. notes of Ternopol. state. ped. Univ. Geography Series, 1, 176-182.

16. Kovalchuk, I., Martyniuk, V. (2013). Landscape-limnological analysis of lake-basin system (case study of lake Nigovische). Ukrainian Geographical Journal. 2, 60-66. https://doi.org/10.15407/ugz2013.02.060

17. Kovalchuk, I.P., Martyniuk, V.A. (2015). Methodology and experience of landscape-limnological research into lake-basin systems of Ukraine. Geography and Natural Resources, 36(3), 305-312. https://doi.org/10.1134/S1875372815030117

18. Kovalchuk, I.P., Martyniuk, V.O. (2016). Constructive and geographical studies of lake-basin systems for the needs of sustainable nature management. Ukrainian geography: modern challenges. Coll. science works in 3-ree v. K., Print-Service, 2, 128-130.

19. Koryitnyiy, L.M. (2001). Basin concept in natural management. Irkutsk: Publishing House of the Institute Geography SO RAN, 163.

20.Landkildehus, F., Søndergaard, M., Beklioglu, M., Adrian, R., Angeler, D. G., Hejzlar, J., Papastergiadou, E., Zingel, P., Çakiroğlu, A. I., Scharfenberger, U., Drakare, S., Nõges, T., Šorf, M., Stefanidis, K., Tavşanoğlu, Ü. N., Trigal, C., Mahdy, A., Papadaki, C., Tuvikene, L., Larsen, S. E., Kernan, M., Jeppesen, E. (2014). Climate change effects on shallow lakes: design and preliminary results of a cross-European climate gradient mesocosm experiment. Estonian Journal of Ecology, 63, 2, 71-89. http://dx.doi.org/10.3176/eco.2014.2.02

21.Liu, X., Zhang, Y., Dong, G., Hou, G., Jiang, M. (2019). Landscape Pattern Changes in the Xingkai Lake Area, Northeast China. Int J Environ Res Public Health. 16(20), 3820. http://dx.doi.org/10.3390/ijerph16203820 
22. Lopuh, P.S., Yakushko, O.F. (2011). General limnology. Lecture course. Minsk: Publishing House BGU, 340.

23. Martyniuk, V.O. (1999). Landscape-limnologic analysis of the basin (lake) geosystem. Sci. notes of Ternopol. state. ped. Univ. Geography Series, 2, 29-36.

24. Martynyuk, V. (2015). Constructive geographical model of the lake-basin specialized recreational system (on the example of the lake Ostrivske, Ukrainian Polesia). Journal of Wetlands Biodiversity, 5, 115-126.

25. Martyniuk, V.O. (2018). Regional landscape-hydrographic GIS-modeling of surface water of Polessia. The natural Environment of Polesie: Features and Prospects for Development. Brest: Alternatyva, Issue 11, 70-73.

26. Martyniuk, V.O. (2019). Hydrographic peculiarities of surface waters of Verhnoprypiatskyi physical and geographical area (Volyn Polessia). Scientific bull. of Kherson state un-ty. Series: Geograph. sciences. 11, $114-123$. http://dx.doi.org/10.32999/ksu2413-7391/2019-11-15

27. Martyniuk, V.O., Andriichuk, S.V., Zubkovych, I.V. (2018). Regional constructive geographical modeling of lakebasin systems of Ukraine. The development of nature sciences: problems and solutions: Conference Proceedings, April 27-28, 2018. Brno: Baltija Publishing, 218-222.

28. Martyniuk, V., Zubkovych, I. (2019). The landscape-lymnological analysis of the key land «Ostrivsky lakes» (Nobel national park, Ukraine). New stages of development of modern science in Ukraine and EU countries: monograph / edited by authors. 7th ed. Riga, Latvia, "Baltija Publishing”, 238-263. http://dx.doi.org/10.30525/978-9934-58815-0-140

29. Mel'nyk, A.V., Miller, H.P. (1993). Landscape monitoring. K., 152.

30. Mooij, W.M., Hülsmann, S., De Senerpont Domis, L.N., Nolet, B.A., Bodelier, P.L.E., Boers, P.C.M., et al. (2005). The impact of climate change on lakes in the Netherlands: a review. Aquatic Ecology, 39, $381-400$. http://dx.doi.org/10.1007/s10452-005-9008-0

31. Nazarova, T., Fomin, I., Dmitriyev, P. Wendt, J., Janaleyeva, K. (2019). Landscape and limnological research of lake system of the plain areas of the northeastern borderlands of the Republic of Kazakhstan and assessment of their recreational capacity. Geojournal of Tourism and Geosites, 25. 485-495. http://dx.doi.org/10.30892/gtg.25217-375

32. Pasztaleniec, A., Kutyta, S. (2015). The Ecological Status of Lakes in National and Landscape Parks: Does the Location of a Lake and Its Catchment within a Protected Area Matter? Pol. J. Environ. Stud. 24 (1), $227-240$. http://dx.doi.org/10.15244/pjoes/24926

33. Peresadko, V.A., Bodnya, O.V. (2010). Geographical modeling of national nature parks. Kharkiv, 28.

34. The list of fishery standards for maximum permissible concentrations (MPC) and tentatively safe levels of exposure (TSLE) of harmful substances for water bodies of fishery importance. (1999). Moscow, VNIRO Publishing House.

35. Robertson, D.M., Siebers, B.J., Diebel, M.W., Somor, A.J., (2018). Water-quality response to changes in phosphorus loading of the Winnebago Pool Lakes, Wisconsin, with special emphasis on the effects of internal loading in a chain of shallow lakes: U.S. Geological Survey Scientific Investigations Report 2018-5099, 58, https://doi.org/10.3133/sir20185099

36. Rudenko, L.G., Golubtsov, A.G., Chekhniy, V.M., Ivanenko, Eu.I., Didukh, Ya.P., Lisovskyi, S.A., Maruniak, Eu.A., Kostiushyn, V.A. (2019). Methodology of territory assessment for the development of protected areas network in Ukraine. Nature management, 1, 37-50.

37. Samoilenko, V.M., Ivanok D.V. (2015). Modeling of basin geosystems: Monograph. K .: SE «Print Service», 208.

38. Sulik, L., Krychevs'ka, D. (2014). An analysis of the structure and geospatial distribution of the nature reserve fund of Volyn Polesia as an important component of the ecotourism potential of the region. Visnyk of the Lviv University. Series Geography, 47, 273-280.

39. Choiński, A., Macias, A. (2008). Jeziora w parkach narodowych, rezerwatach przyrody i parkach krajobrazowych Polski pótnocnej i środkowej. Wody na obszarach chronionych. J. Partyka, J. Pociask-Karteczka (red.) Instytut Geografii i Gospodarki Przestrzennej UJ, Ojcowski Park Narodowy, Komisja Hydrologiczna PTG. Kraków, 31-42.

40. Management of the transboundary basin of the Dnieper: the sub-basin of the river Pripyat: monograph; under the editorship of A.G. Obodovskyi, A.P. Stankevich, S.A. Afanasiev. (2012). K., Department, 448.

41. Havens, K., Jeppesen, E. (2018). Ecological Responses of Lakes to Climate Change. Water. 10(7):917. http://dx.doi.org/10.3390/w10070917 